\title{
KESADARAN HUKUM MASYARAKAT DALAM KEPEMILIKAN AKTA PERKAWINAN
}

\author{
Wayan Resmini' ${ }^{1}$, Abdul Sakban ${ }^{1)}$, Ni Putu Ade Resmayani2) \\ 1)Program Studi PPKn, FKIP Universitas Muhammadiyah Mataram, Mataram, Indonesia \\ 2)Program Studi Pariwisata, Sekolah Tinggi Pariwisata Mataram, Mataram, Indonesia \\ Corresponding author: Wayan Resmini \\ E-mail : wayanresmini@ymail.com
}

\section{Diterima 03 November 2020, Direvisi 17 November 2020, Disetujui 17 November 2020}

\begin{abstract}
ABSTRAK
Kesadaran hukum merupakan sikap yang perlu ditanamkan kepada seluruh warga masyarakat dalam kehidupan berbangsa dan bernegara untuk meningkatkan kesadaran hukum, seyogyanya dilakukan melalui penerangan dan penyuluhan hukum yang teratur atas dasar rencana yang mantap, misalnya mengenai Undang-Undang No I Tahun 1974 tentang Perkawinan. Uraian di atas jika dihubungkan dengan realitas di lapangan, masih banyak masyarakat yang belum mematuhi hukum, hal ini dapat dilihat dalam kepemilikan akta perkawinan, yang merupakan kewajiban bagi kelangsungan kehidupan suatu rumah tangga. Peran dari Kantor Urusan Agama (KUA) bagi yang beragama Islam dan juga Kantor Catatan Sipil bagi yang beragama diluar Islam, selaku yang membuat akta perkawinan sangat penting. Lokasi pengabdian pada masyarakat ini dilakukan di kecamatan Pemenang, berjarak sekitar $9 \mathrm{~km}$ dari kabupaten Lombok Utara, Provinsi Nusa Tenggara Barat. Adapun tujuan kegiatan ini adalah : untuk meningkatkan kesadaran hukum masyarakat terhadap kepemilikan akta perkawinan. Metode yang dipergunakan dalam kegiatan ini adalah: penyuluhan dan tanya jawab. Dalam meningkatkan kesadaran masyarakat terhadap kepemilikan Akta Perkawinan di kecamatan Pemenang, kabupaten Lombok Utara merupakan suatu hal yang harus ditingkatkan, ini membuktikan bahwa peran serta Kantor Urusan Agama dan Kantor Catatan Sipil sangatlah diperlukan dengan melihat hasil pengamatan dan Tanya jawab pada saat dilaksanakan pengabdian pada masyarakat bahwa peran serta pemerintah belum maksimal, karena metode penyuluhan yang dilakukan selama ini belum mampu meningkatkan kesadaran masyarakat secara keseluruhan dengan melihat kenyataan yang terjadi dalam masyarakat. Faktor ekonomi yang masih rendah membuat masyarakat tidak memiliki akta perkawinan, biaya merupakan faktor yang menjadi kendala masyarakat dalam membuat akta perkawinan, faktor lain yang menghambat masyarakat dalam kepemilikan akta perkawinan, yaitu faktor kesadaran masyarakat yang masih rendah dengan melihat tingkat pendidikan masyarakatnya.
\end{abstract}

Kata kunci : kesadaran hukum; kepemilikan; akta perkawinan

\begin{abstract}
Legal awareness is an attitude that needs to be instilled in all community members of the nation. Regular information and legal counseling based on a solid plan need to have existed to increase legal awareness, for example, regarding Law No. I of 1974 concerning Marriage. If the description above is related to the reality on the ground, many people have not obeyed the law. This matter can be seen in the ownership of a marriage certificate, which is an obligation for each household. The role of the Office of Religious Affairs (KUA) for those who are Muslim and also the Civil Registry Office for those who are non-Muslim, as the one who makes marriage certificates, is critical. This community service is carried out in Pemenang district, about $9 \mathrm{~km}$ from North Lombok district, West Nusa Tenggara Province. This activity aims to increase legal awareness of the community towards ownership of a marriage certificate. The methods used in this activity were: counseling, along with questions and answers session. In increasing public awareness of ownership of a Marriage Certificate in Pemenang, the Office of Religious Affairs and the Civil Registry Office of North Lombok Provence is needed by looking at the results of observations and questions and answers during community service. The government's participation has not been maximized because the counseling methods so far have not been able to increase public awareness as a whole by looking at the reality that occurs in society. Economic factors that still low make people not have a marriage certificate; the cost is a factor that becomes a constraint for society in obtaining a marriage certificate. These other factors hinder people from having a marriage certificate, namely the factor of community awareness that is still low by looking at the community's level of education.
\end{abstract}

Keywords: legal awareness; ownership; marriage certificate 


\section{PENDAHULUAN}

Kesadaran hukum merupakan sikap yang perlu ditanamkan kepada seluruh warga masyarakat dalam kehidupan berbangsa dan bernegara, tentunya dalam mematuhi hukum harus ada kesadaran dalam diri masyarakat setempat dengan demikian kesadaran masyarakat dalam tatanan kehidupan harus dijunjung tinggi agar dalam proses kehidupan akan dapat berjalan dengan baik.

Menurut Soejono Soekanto bahwa Kesadaran hukum yang tinggi mengakibatkan warga masyarakat mematuhi ketentuan hukum yang berlaku. Sebaliknya apabila kesadaran hukum sangat rendah, maka derajat kepatuhan terhadap hukum juga tidak tinggi (2014:59)

Berfungsinya hukum dalam masyarakat atau efektivitas dari ketentuan hukum di dalam pelaksanaannya. Seorang yang mempunyai kesadaran hukum, akan memiliki penilaian terhadap hukum yang dinilai dari segi tujuan dan tugasnya. Penilaian semacam ini ada pada setiap warga masyarakat, oleh karena itu manusia pada umumnya mempunyai hasrat untuk senantiasa hidup dengan teratur. Kesadaran hukum merupakan suatu proses psikis yang terdapat dalam diri manusia, yang mungkin timbul dan juga mungkin tidak timbul. kesadaran hukum merupakan kesadaran atau nilai-nilai yang terdapat di dalam diri manusia tentang hukum yang ada atau tentang hukum yang diharapkan ada (Soekanto.2007:21).

Dengan demikian, jelaslah bahwa kesadaran hukum sebelumnya menjadi dasar bagi penegakan hukum sebagai proses, untuk meningkatkan kesadaran hukum, seyogianya dilakukan melalui penerangan dan penyuluhan hukum yang teratur atas dasar rencana yang mantap. Penerangan hukum bertujuan agar warga masyarakat mengetahui mengenai hukum tertentu, seperti peraturan perundangundangan tertentu misalnya mengenai perkawinan dan lain-lain yang dijelaskan melalui penerangan hukum.

Perkawinan merupakan salah satu peristiwa penting dalam kehidupan manusia. Perkawinan yang terjadi antara seorang pria dengan seorang wanita menimbulkan akibat lahir maupun batin baik terhadap keluarga masing-masing masyarakat dan juga dengan harta kekayaan yang diperoleh diantara mereka baik sebelum maupun selama perkawinan berlangsung. Pasal 26 Kitab Undang-Undang Hukum Perdata (KUHP) menyatakan bahwa perkawinan ialah pertalian yang sah antara seorang laki-laki dan seorang perempuan untuk waktu yang lama. KUH Perdata memandang bahwa perkawinan hanya berdasarkan hubungan keperdataan saja. Artinya bahwa suatu perkawinan yang sah, hanyalah perkawinan yang memenuhi syarat syarat yang ditetapkan dalam KUH Perdata .

Undang-Undang No. 1 Tahun 1974 tentang Perkawinan, Pasal 1 menyatakan bahwa perkawinan adalah ikatan lahir dan batin antara seorang pria dan seorang wanita sebagai suami istri dengan tujuan membentuk keluarga (rumah tangga) yang bahagia dan kekal dengan berdasarkan Tuhan Yang Maha Esa. Suatu perbuatan seperti perkawinan baru dikatakan perbuatan hukum apabila dilakukan menurut ketentuan hukum yang berlaku secara positif. Ketentuan hukum yang mengatur mengenai tata cara perkawinan yang dibenarkan oleh hukum di Indonesia seperti yang diatur dalam Undang-Undang Nomor 1 Tahun 1974 tentang Perkawinan, dengan tata cara demikianlah yang mempunyai akibat hukum, yakni akibat yang mempunyai hak mendapat pengakuan dan perlindungan hukum. Uraian di atas jika dihubungkan dengan realitas di lapangan, masih banyak sekali masyarakat yang belum mematuhi hukum, hal ini dapat dilihat dalam kepemilikan akta perkawinan, ini berarti dapat mengindikasikan bahwa kesadaran masyarakat yang masih minim, padahal dalam kepemilikan akta perkawinan bagi masyarakat yang sudah berkeluarga merupakan suatu yang menjadi kewajiban bagi kelangsungan kehidupan suatu rumah tangga.

Peran dari Kantor Urusan Agama (KUA) bagi yang beragama Islam dan juga Kantor Catatan Sipil bagi yang beragama diluar Islam, selaku yang membuat akta perkawinan sangat penting, dengan melihat masih banyaknya masyarakat yang sudah berumah tangga tetapi belum memiliki akta perkawinan dalam artian ini mengindifikasi bahwa kurangnya peran dari kantor urusan tersebut dalam melakukan sosialisasi kepada masyarakat. Karena nantinya dapat berpengaruh sangat besar apabila masyarakat tidak memiliki akta perkawinan antara lain: dalam pembuatan kartu keluarga, akta kelahiran dan lainnya, dengan demikian peran dari lembaga yang bersangkutan sangat diperlukan, dimana aktivitas masyarakatnya meningkat, masyarakatnya kurang paham terhadap peraturan yang sangat penting dalam kehidupan rumah tangganya, untuk itu sangat diperlukan akses informasi guna meningkatkan wawasan dan pengetahuan dan daya saing, daya tahan diri terhadap lingkungan, keluarga di sekitarnya. Sehubungan dengan hal tersebut, perlu diberikan informasi tentang segala sesuatu yang berhubungan dengan masalah kepemilikan akta perkawinan, hal ini disebabkan karena masyarakat setempat menganggap bahwa memiliki akta perkawinan 
adalah suatu yang biasa saja, disamping itu kurangnya sosialisasi yang dilakukan oleh pihak yang berwenang terhadap masyarakat, sehingga masyarakat yang tidak terlalu paham dengan pentingnya akta perkawinan merasa itu hal yang biasa dalam memiliki akta perkawinan bagi keluarga yang sudah berumah tangga. Lokasi pengabdian pada masyarakat ini dilakukan di kecamatan Pemenang, berjarak sekitar $9 \mathrm{~km}$ dari kabupaten Lombok Utara, Provinsi Nusa Tenggara Barat. . Adapun tujuan kegiatan ini adalah : untuk meningkatkan kesadaran hukum masyarakat terhadap kepemilikan akta perkawinan. Metode yang dipergunakan dalam kegiatan ini adalah: penyuluhan dan tanya jawab.

\section{METODE}

Pelaksanaan penyuluhan hukum dalam kegiatan pengabdian masyarakat ini lokasinya di kecamatan Pemenang, berjarak sekitar $9 \mathrm{~km}$ dari kabupaten Lombok Utara, Provinsi Nusa Tenggara Barat. Kegiatan penyuluhan hukum tentang Kesadaran Hukum Masyarakat Dalam Kepemilikan Akta Perkawinan diadakan oleh Tim Pengabdian Masyarakat Program Studi PPKn FKIP Universitas Muhammadiyah Mataram dengan melibatkan juga Tim Pengabdian Masyarakat Sekolah Tinggi Pariwisata Mataram dan kantor Kecamatan Pemenang, Kabupaten Lombok Utara. Peyuluhan hukum dilaksanakan secara langsung dengan memperhatikan peraturan dan tata tertib kesehatan (covid 19 yaitu mempergunakan masker, mengatur jarak dan mencuci tangan), dengan jumlah subyek/sasaran sebanyak 20 orang terdiri dari tokoh adat,tokoh masyarakat,tokoh agama dan perwakilan dari masyarakat, yang nantinya mereka diharapkan dapat mensosialisasikan kepada masyarakat lainnya tentang betapa pentingnya kepemilikan akta perkawinan dalam kehidupan berumah tangga, misalnya pada saat ada kegiatan keagaman, kegiatan budaya, pertemuan lainnya yang melibatkan masyarakat banyak. Metode kegiatan mempergunakan dua pendekatan yaitu pertama pendekatan teoritis yang terdiri dari pemaparan materi dengan metode ceramah, sedangkan pendekatan kedua dengan metode diskusi dan tanya jawab.

\section{HASIL DAN PEMBAHASAN}

Kesadaran hukum merupakan salah satu ciri bahwa masyarakat telah memahami dan mengerti hukum. Kesadaran hukum warga negara dapat terlihat dari perilaku dimana dia berada (Ali,2010:13). Kesadaran hukum adalah kesadaran yang ada pada setiap manusia tentang apa hukum itu atau apa seharusnya hukum itu, suatu ketegori tertentu dari hidup kejiwaan, dengan membedakan antara hukum dan tidak hukum, antara lain seyogyanya dilakukan dan tidak seyogyanya dilakukan (Scholten, 2004:166).

Berdasarkan pendapat di atas, faktor yang mempengaruhi kesadaran hukum merupakan faktor yang mendorong masyarakat terhadap ketentuan-ketentuan hukum, berarti bahwa masyarakat mengetahui isi dan kegunaan dari norma-norma hukum tertentu. Artinya ada suatu derajat pemahaman yang tertentu terhadap ketentuan-ketentuan hukum yang berlaku.

Pengertian Masyarakat menurut Soekanto, (2014:147) menyatakan bahwa masyarakat adalah orang yang hidup bersama yang menghasilkan kebudayaan. Dengan demikian, tak ada masyarakat yang tidak mempunyai kebudayaan dan sebaliknya tak ada kebudayaan tanpa masyarakat sebagai wadah dan pendukungnya. masyarakat merupakan sekumpulan manusia yang relatif mandiri, hidup bersama cukup lama, mendiami wilayah tertentu, memiliki kebudayaan yang sama dan melakukan sebagian besar kegiatan dalam kelompok tersebut. Di lain pihak, la menyatakan masyarakat adalah organisasi manusia yang saling berhubungan satu dan lainnya. Koentjaraningrat menyatakan bahwa:

Masyarakat adalah sekelompok manusia yang bekerja sama dalam mengejar beberapa kepentingan utama mereka, termasuk memelihara diri dan kelangsungan hidup, konsep masyarakat termaksuk kesinambungan, hubungan asosiasional yang kompleks, dan komposisi termasuk perwakilan dari jenis manusia yang mendasar, khususnya laki-laki wanita dan anak-anak. Atau dengan kata lain dapat diartikan bahwa masyarakat adalah kesatuan dari mahluk-mahluk manusia yang terkait oleh sistem alat dan adat tertentu (2007:135).

Berdasarkan hal tersebut di atas, maka masyarakat setempat (community) atau komunitas adalah suatu kebersamaan hidup sejumlah orang banyak yang memiliki ciri-ciri. (1) teritorialitas yang terbatas (keorganisasian tata hidup bersama dan (3) berlakunya nilainilai dan orientasi nilai yang kolektif. Masyarakat setempat (community) menunjuk pada bagian warga masyarakat yang bertempat tinggal disuatu wilayah geografis dengan batasbatas tertentu dengan faktor utama yang menjadi dasarnya adalah interaksi yang lebih besar di antara anggota, dibandingkan dengan interaksi penduduk di luar batas wilayahnnya. Masyarakat setempat (community) adalah warga sebuah desa, kota, suku atau bangsa. Jika anggota-anggota suatu kelompok tersebut, 
baik kelompok itu besar maupun kelompok itu kecil, hidup bersama sedemikian rupa sehingga merasakan bahwa kelompok tersebut dapat memenuhi kepentingan-kepentingan hidup yang utama, maka kelompok tadi disebut masyarakat setempat.

Struktur masyarakat Indonesia ditandai oleh dua cirinya yang bersifat unik. Secara horizontal, ia ditandai oleh kenyataan adanya kesatuan-kesatuan social berdasarkan perbedaan-perbedaan suku bangsa, perbedaan agama, adat serta perbedaan kedaerahan. Secara vertikal, struktur masyarakat Indonesia ditandai oleh adanya perbedaan-perbedaan vertikal antara lapisan atas dan lapisan bawah yang cukup tajam.

Perbedaan-perbedaan suku-bangsa, perbedaan agama, adat dan kedaerahan sering kali disebut sebagai ciri masyarakat Indonesia yang bersifat majemuk, suatu istilah yang mulamula sekali diperkenalkan oleh Furnivall untuk menggambarkan masyarakat Indonesia pada masa Hindia Belanda. Konsep masyarakat majemuk sebagaimana yang banyak dipergunakan oleh ahli-ahli ilmu kemasyarakatan dewasa ini memang merupakan perluasan dari konsep Furnivall tersebut. ( Nasikun $2013: 32$ )

Pencatatan perkawinan adalah kegiatan pengadministrasian dari sebuah perkawinan yang dilakukan oleh pegawai pencatatan nikah (PPN) yang berkedudukan di Kantor Urusan Agama (KUA) di wilayah kedua calon mempelai melangsungkan perkawinan yang beragama islam, dan di kantor catatan sipil (KCS) bagi yang beragama selain dari yang beragama Islam

Untuk sahnya suatu perkawinan ditinjau dari sudut keperdataan adalah jika perkawinan sudah dicatat atau didaftarkan di Kantor Urusan Agama atau Kantor Urusan Sipil sesuai dengan agama yang dianutnya. Selama perkawinan ini belum terdaftar, perkawinan itu masih belum dianggap sah menurut ketentuan hukum negara Indonesia sekalipun mereka sudah memenuhi prosedur dan tata cara menurut ketentuan Agama (Anshary. 2015:31). Sedangkan ditinjau sebagai suatu perbuatan keagamaam pencatatan nikah hanyalah sekedar memenuhi administrasi perkawinan saja yang tidak menentukan sah atau tidaknya suatu perkawinan. Ketentuan mengenai pencatatan nikah diatur dalam UndangUndang No. 1 Tahun 1974 tentang Perkawinan pada Pasal 2 ayat ( 2) dan kompilasi hukum Islam Pasal 5 ayat (1) berbunyi "Agar terjamin ketertiban perkawinan bagi masyarakat Islam setiap perkawinan harus dicatat" Pencatatan nikah sangat penting dilaksanakan oleh pasangan mempelai sebab buku nikah yang mereka peroleh merupakan bukti otentik tentang keabsahan pernikahan baik secara agama maupun negara Indonesia. Dengan buku nikah, mereka dapat membuktikan pula keturunan sah yang dihasilkan dari perkawinan tersebut dan memperoleh hak-haknya sebagai ahli waris.

Kesadaran hukum adalah kesadaran yang ada pada setiap manusia tentang apa yang boleh dilakukan dan yang tidak boleh dilakukan. masyarakat mengetahui isi dan kegunaan dari norma-norma hukum tertentu, seperti kesadaran masyarakat terhadap kepemilikan akte perkawinan. Untuk itu masyarakat seharusnya mengetahui proses yang harus dilakukan sebelum dan sesudah melaksanakan perkawinan diantaranya masyarakat harus melakukan pencatatan perkawinannya. Ketentuan hukum yang mewajibkan pencatatan perkawinan terdapat pada :

1. UU No. 1 Tahun 1974 tentang Perkawinan, yaitu terdapat dalam Pasal 2 ayat (2): "Tiap-tiap perkawinan dicatat menurut Peraturan Perundangundangan yang berlaku."

2. Peraturan pemerintah (PP) No. 9 Tahun 1975 tentang Peraturan Pelaksana Undang-Undang No 1 Tahun 1974 tentang Perkawinan Pasal 2

3. Pencatatan perkawinan dari mereka yang melangsungkan perkawinannya meurut agama islam, dilakukan oleh pegawai pencatat sebagaimana dimaksudkan dalam Undang-Undang No 32 Tahun 1954 tentang pencatatan nikah, talak,dan rujuk.

4. Pencatatan perkawinan dari mereka yang melangsungkan perkawinannya menurut agamanya dan kepercayaannya itu selain agama islam, dilakukan oleh pegawai pencatat perkawinan pada kantor catatan sipil sebagaimana dimaksud dalam berbagai perundang-undangan mengenai pencatatan perkawinan.

5. Dengan tidak mengurangi ketentuanketentuan yang khusus berlaku bagi tata cara pencatatan perkawinan berdasarkan berbagai peraturan yang berlaku, tata cara pencatatan perkawinan dilakukan sebagaimana ditentukan dalam Pasal 3 sampai dengan Pasal 9 peraturan pemerintah ini.

Pencatatan perkawinan bertujuan untuk mewujudkan ketertiban perkawinan dalam masyarakat, ini merupakan suatu upaya 
yang diatur melalui perundang-undangan untuk melindungi martabat dan kesucian perkawinan dan khususnya pertemuan dalam kehidupan rumah tangga. Melalui pencatatan perkawinan yang dibuktikan oleh akta, apabila terjadi perselisihan di antara suami istri, maka salah satu diantaranya dapat melakukan upaya hukum guna mempertahankan atau memperoleh hak masing-masing. Karena dengan akta tersebut, suami isteri memiliki bukti autentik atas perbuatan hukum yang telah mereka lakukan.

Pencatatan perkawinan juga berfungsi sebagai pengatur lalu lintas praktik poligami yang sering dilakukan secara diam-diam oleh pihak-pihak tertentu yang hanya menjadikan nikah di bawah tangan tanpa pencatatan sebagai alat poligami atau poliandri. Setiap pasangan yang akan menikah di KUA (Kantor Urusan Agama) atau Kantor Catatan Sipil (KCS) biasanya melalui mekanisme pengumuman status calon mempelai setelah terdaftar sebagai pasangan yang hendak menikah. Ketika data tentang status masingmasing calon mempelai diumumkan dan ternyata ada yang keberatan, perkawinan bisa saja batal. Dalam meningkatkan kesadaran masyarakat dalam kepemilikan Akta Perkawinan di kecamatan Pemenang, kabupaten Lombok Utara merupakan suatu hal yang harus ditingkatkan, ini membuktikan bahwa peran serta Kantor Urusan Agama bagi yang beragama Islam dan Kantor Catatan Sipil bagi yang bukan pemeluk agama Islam sangatlah diperlukan dengan melihat hasil pengamatan dan Tanya jawab pada saat dilaksanakan pengabdian pada masyarakat bahwa peran serta pemerintah belum maksimal, karena metode penyuluhan yang dilakukan selama ini belum mampu meningkatkan kesadaran masyarakat secara keseluruhan dengan melihat kenyataan yang terjadi dalam masyarakat. Hal ini disebabkan karena berbagai factor antara lain; ekonomi dan tingkat tingkat pendidikan masyarakat.

Faktor ekonomi yang masih rendah membuat masyarakat tidak memiliki akta perkawinan, biaya merupakan faktor yang menjadi kendala masyarakat dalam membuat akta perkawinan, tingkat ekonomi yang tidak mendukung membuat masyarakat tidak bisa membuat akta perkawinan.

Faktor lain yang menghambat masyarakat dalam kepemilikan akta perkawinan, yaitu faktor kesadaran masyarakat yang masih rendah karena dipengaruhi oleh tingkat pendidikan masyarakat.

\section{SIMPULAN DAN SARAN Simpulan}

Berdasarkan penjelasan di atas dapat ditarik kesimpulan antara lain: Dalam meningkatkan kesadaran masyarakat untuk memiliki Akta Perkawinan di kecamatan Pemenang, kabupaten Lombok Utara merupakan suatu hal yang harus ditingkatkan, ini membuktikan bahwa peran serta Kantor Urusan Agama bagi yang beragama Islam dan Kantor Catatan Sipil bagi yang bukan pemeluk agama Islam sangatlah diperlukan dengan melihat hasil pengamatan dan Tanya jawab pada saat dilaksanakan pengabdian pada masyarakat bahwa peran serta pemerintah belum maksimal, karena metode penyuluhan yang dilakukan selama ini belum mampu meningkatkan kesadaran masyarakat secara keseluruhan dengan melihat kenyataan yang terjadi dalam masyarakat.

Faktor ekonomi yang masih rendah membuat masyarakat tidak memiliki akta perkawinan, biaya merupakan faktor yang menjadi kendala masyarakat dalam membuat akta perkawinan, ekonomi yang tidak mendukung sehingga masyarakat tidak bisa membuat akta perkawinan.

Faktor lain yang menghambat masyarakat dalam kepemilikan akta perkawinan, yaitu faktor kesadaran masyarakat yang masih rendah dengan memperhatikan tingkat pendidikan masyarakat.

\section{Saran}

Kepada Pemerintah Kantor Urusan Agama, Kantor Catatan Sipil pemerintah kecamatan Pemenang, tokoh masyarakat dan tokoh agama agar sekiranya meningkatkan peran dalam melakukan penyuluhan, dan memberi arahan, kepada masyarakat agar masyarakat yang bersangkatun sadar dengan arti penting akta perkawinan sebagai payung hukum dalam kehidupan masyarakat setempat.

Bagi masyarakat setempat supaya selalu meningkatkan kesadaran dalam membuat akta pekawinan, karena akta perkawinan merupakan landasan hukum/payung hukum dalam hidup berumah tangga dan ini sangat penting bagi masyarakat yang sudah menikah.

\section{DAFTAR RUJUKAN}

Ali. 2010. Kesadaran Hukum. Jakarta: Erlangga.

Anshary. 2015. Hukum Perkawinan Di Indonesia. Yogyakarta: Pustaka Pelajar.

Indonesia, Republik. 1974. Undang-Undang No 1 Tahun 1974 Tentang Perkawinan. 1975. Peraturan Pemerintah (PP) No. 9 Tahun 1975 Tentang Peraturan 
Pelaksana Undang-Undang No 1 Tahun 1974 Tentang Perkawinan.

. Kitab Undang-Undang Hukum Perdata.

Koentjaraningrat. 2007. Pengantar IImu Antropologi. Jakarta: Aksara Baru.

Nasikun. 2013. System Social Indonesia. Yokyakarta: Ombak.

Scholten. 2014. Kartu Tanda Penduduk. Jakarta: Erlangga.

Soekanto. 2014. Konsep Kesadaran Hukum. Jakarta: Erlangga.

Soerjono, Soekanto. 2014. Sosiologi Suatu Pengantar. Jakarta: Rajagrafindo Persada. 